Journal

of Geography,

Politics and Society

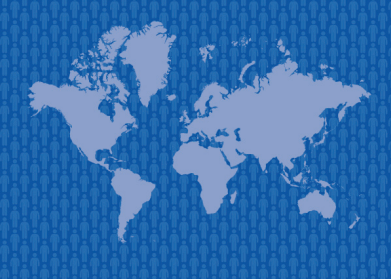

$10(4) / 2020$

\section{Journal of Geography, Politics and Society}

2020, 10(4), 23-32

https://doi.org/10.26881/jpgs.2020.4.04

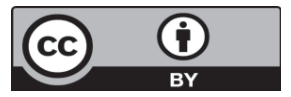

\title{
POPULATION OF THE NORTH CAUCASUS AT THE PRESENT STAGE: INDICATORS OF REGIONAL DIFFERENTIATION
}

\author{
Vera V. Minenkova (1), Anna V. Kazalieva (2) \\ (1) Institute of Geography, Geology, Tourism and Service, Kuban State University, Stavropolskaya 149, 350040 Krasnodar, Russia, ORCID $0000-0003-4184-2522$ \\ e-mail: minenkova@inbox.ru (corresponding author) \\ (2) Institute of Geography, Geology, Tourism and Service, Kuban State University, Stavropolskaya 149, 350040 Krasnodar, Russia. \\ e-mail: kazalieva.an@yandex.ru
}

\section{Citation}

Minenkova V.V., Kazalieva A.V., 2020, Population of the north Caucasus in the present stage: indicators of regional differentiation, Journal of Geography, Politics and Society, 10(4), 23-32.

\begin{abstract}
Based on the collected statistical material, the analysis of population changes in the North Caucasus regions since the last allRussian population census until 2018 was conducted. The article considers the main factors of the current population reproduction, and trends in the dynamics of the population in the North Caucasus were set. Based on the obtained data, the subjects of the North Caucasus are divided into two categories. The first are Russian-speaking regions where the absolute population growth is observed due to a positive migration balance that covers the natural decline of the population. The other category includes mainly national republics with a high natural growth that covers a significant migration outflow of the population. Despite the favorable demographic situation in the region under study, there is a trend towards the end of the demographic boom that is typical of the entire North Caucasus region. In general, there is a stabilization of the birth rate and natural growth, and a decrease in the intensity of migration movements.
\end{abstract}

\section{Key words}

population reproduction, migration, North Caucasus.

Received: 14 August 2020

Accepted: 12 November 2020

Published: 31 December 2020

\section{Introduction}

Throughout the 20th century, the population of Russia was growing steadily, until 1992. With the collapse of the Soviet Union, the number of inhabitants began to decline steadily, mainly due to migration, as well as due to natural population loss. Every year the demographic situation in the Russian Federation became more alarming. The population of the country gradually decreased, thus having a negative impact on socio-economic processes and threatening the territorial integrity of the country (Kazalieva et al., 2018).

In 2010, as a result of the government's implementation of a new demographic policy, for the first time since the 1990s, a positive increase in the country's population was recorded, which occurred only due to a positive migration balance. In 2013 for the first time after a 20-year break, natural population growth was registered in Russia. 
The North Caucasus is one of the few regions of the Russian Federation where, despite the all-Russian trend, the population has continued to grow, both throughout the crisis period and at the present time.

This article examines the dynamics and factors of population change in the North Caucasus. The subjects located on the territory of the North Caucasus as a geographical object are analyzed. For this reason, data for the Rostov region are not included in this study.

The article is based on the application of statistical and comparative geographical methods. Statistical information obtained from the official data of the Federal state statistics service of the Russian Federation is used.

\section{Results and Discussion}

According to official data for 2020, the population of the North Caucasus was 16,070 thousand people, or $11 \%$ of the total population of the Russian Federation. The population has increased by 1 million since 2010, which indicates a positive dynamics of population reproduction.

Table 1 reflects the absolute population size by year of both the North Caucasus as a whole and each region separately.

Krasnodar region holds the leading position in terms of absolute population among the regional subjects and has had a stable population growth of $8.6 \%$ over the past 10 years. The largest population growth is observed in the Republic of Ingushetia (23\%), the Chechen Republic (16.5\%), the Republic of Dagestan (6.9\%), and the Republic of Adygea (5.3\%). Kabardino-Balkaria and the Stavropol Region complete the list with a slight increase in population $-1 \%$ and $0.6 \%$, respectively.

The republics of North Ossetia-Alania and Karachay-Cherkessia are subjects with negative population dynamics for the period under review. Compared to 2010 , by the beginning of 2020 , the population of these regions has decreased by $2.2 \%$ and $2.6 \%$, respectively (Kazalieva, Minenkova, 2019).

Thus, the most intensive population growth occurs in the Chechen Republic and Ingushetia, followed by the Krasnodar region and the Republic of Dagestan. The Chechen Republic (14.9 people per 1000 population) is the leader in natural population growth in the North Caucasus (fig.1), followed by the republics of Ingushetia (13 people per 1000 population) and Dagestan (10 people per 1000 population).

Growth in the Chechen Republic and the Republic of Ingushetia peaked in 2010-2011. This situation is explained by the fairly stable national traditions of these republics. In contrast to other regions of the country, there is the least number of divorces and traditionally a large number of children in families. Among other things, these three republics have the lowest mortality rates and the highest number of centenarians. The decrease in natural growth in

Tab. 1. Dynamics of the population of Russia and the North Caucasus regions from 2010 to 2020 (thousand people; data for January 1 of each year)

\begin{tabular}{|c|c|c|c|c|c|c|c|c|c|c|c|}
\hline$\stackrel{\bar{\varpi}}{\stackrel{\varpi}{๘}}$ & 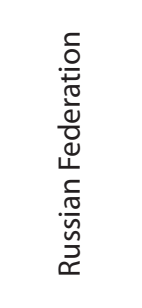 & 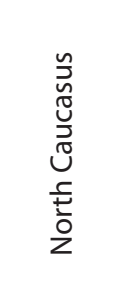 & 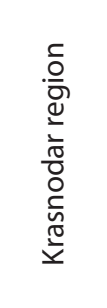 & 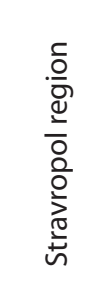 & 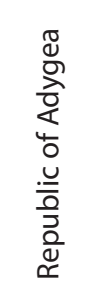 & 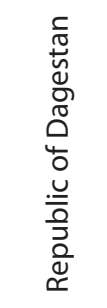 & 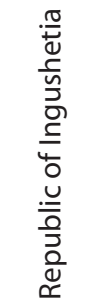 & 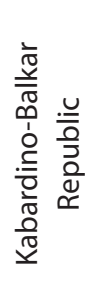 & 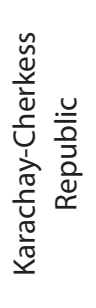 & 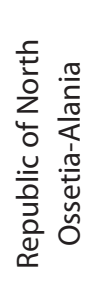 & 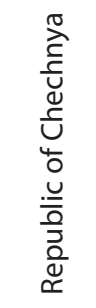 \\
\hline 2010 & 143263.0 & 15095.3 & 5226.6 & 2786.3 & 439.8 & 2910.2 & 412.5 & 859.9 & 477.9 & 713.0 & 1269.0 \\
\hline 2011 & 142865.0 & 15109.2 & 5230.0 & 2786.0 & 440.0 & 2914.2 & 415.0 & 860.0 & 477.0 & 712.0 & 1275.0 \\
\hline 2012 & 143056.0 & 15219.0 & 5283.4 & 2787.0 & 443.0 & 2930.4 & 430.0 & 859.0 & 475.0 & 709.0 & 1302.0 \\
\hline 2013 & 143347.0 & 15316.2 & 5330.2 & 2791.0 & 445.0 & 2946.0 & 442.0 & 859.0 & 472.0 & 706.0 & 1325.0 \\
\hline 2014 & 143667.0 & 15440.3 & 5404.3 & 2794.0 & 446.0 & 2963.9 & 453.0 & 859.0 & 470.0 & 704.0 & 1346.0 \\
\hline 2015 & 146267.0 & 15561.7 & 5453.3 & 2799.0 & 449.0 & 2990.4 & 464.0 & 861.0 & 469.0 & 706.0 & 1370.0 \\
\hline 2016 & 146545.0 & 15683.5 & 5513.8 & 2802.0 & 451.0 & 3015.7 & 473.0 & 862.0 & 468.0 & 704.0 & 1394.0 \\
\hline 2017 & 146804.0 & 15800.9 & 5570.9 & 2804.0 & 454.0 & 3042.0 & 481.0 & 865.0 & 466.0 & 703.0 & 1415.0 \\
\hline 2018 & 146880.0 & 15880.0 & 5603.4 & 2801.0 & 454.0 & 3064.0 & 488.0 & 865.0 & 466.0 & 702.0 & 1437.0 \\
\hline 2019 & 146781.0 & 15970.0 & 5648.2 & 2795.2 & 455.0 & 3086.1 & 497.4 & 866.2 & 465.6 & 699.3 & 1457.0 \\
\hline 2020 & 146749.0 & 16070.0 & 5675.5 & 2803.6 & 463.1 & 3110.9 & 507.1 & 868.4 & 465.5 & 697.0 & 1478.7 \\
\hline
\end{tabular}

Source: Regiony..., Čislennost'... 


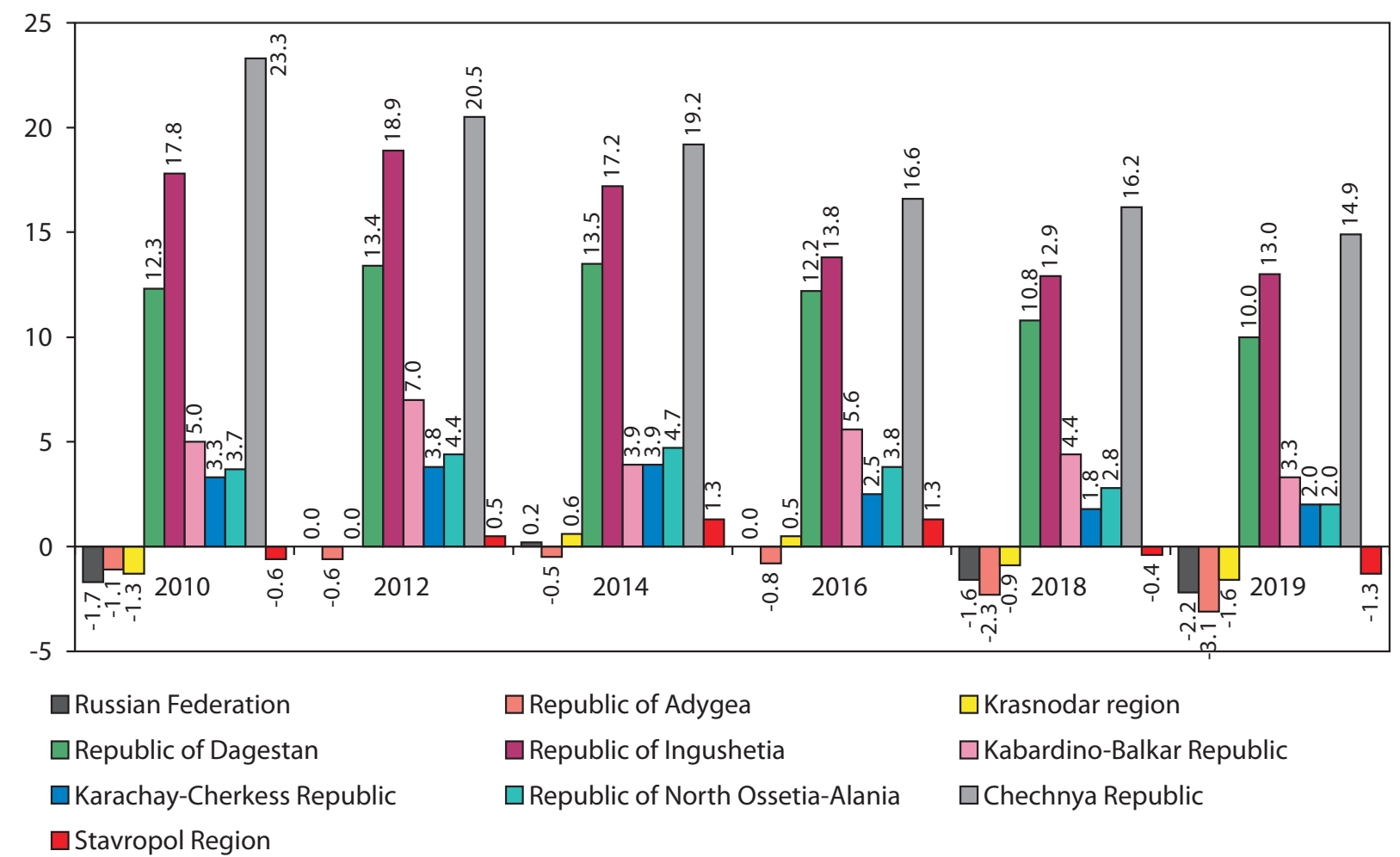

Fig. 1. Dynamics of changes in natural population growth rates in the North Caucasus regions from 2010 to 2018 (per 1 thousand population)

Source: Estestvennyj...

recent years is explained by the fact that, for example, in the Chechen Republic there is a steady trend towards a decrease in the birth rate. According to the state statistics Committee, 28.1 thousand people were born in Chechnya in 2019, while in 2016 - 30 thousand, and in $2010-37.8$ thousand people. As a result, in 2018, the birth rate in Chechnya decreased to $20.2 \%$, and in 2019 - already $19.2 \%$. Nevertheless, the birth rate in the republic is significantly higher than the national average (Dinaev, 2016).

The birth rate is quite high in the Republic of Ingushetia $-15.9 \%$, followed by Dagestan with an indicator of $14.7 \%$ and North Ossetia $-12.3 \%$. The lowest rates were recorded in the Krasnodar and Stavropol regions $-10.8 \%$ and $10.0 \%$, respectively. The lowest birth rate was recorded in the Republic of Adygea $9.3 \%$, which is lower than the national average.

Mortality rates are steadily decreasing in all regions of the North Caucasus (Minenkova, Kazalieva, 2020). The lowest mortality rate in Russia in 2019 was observed in Ingushetia - 2.9\% (in 2010 - 3.6\%), followed by the Chechen Republic - 4.3\% (in 2010 5.3\%), Dagestan - 4.7\% (in $2010-6.2 \%$ ), KabardinoBalkaria - 8.2\% (in 2010 - 9\%), Karachay-Cherkessia - 9\% (in 2010 - 11.5\%), North Ossetia - 10.3\% (in 2010. - 11.1\%), Stavropol region - 11.3\% (in 2010 $12.2 \%)$. The highest mortality rates are in the Krasnodar region and the Republic of Adygea - 12.4\%.
At the same time, the decrease in the death rate does not compensate for the decrease in the birth rate; the rate of natural population growth decreases (fig. 1).

The natural population growth rate is also positive in the following republics: Kabardino-Balkaria (3.3 people per 1000 population), North Ossetia-Alania (2 people per 1000 population) and KarachayCherkessia (2 people per 1000 population).

The situation with natural growth is less favorable in the Republic of Adygea and the Krasnodar region (the annual population loss in both subjects is on average 0.5 people per 1000 population). In the period from 2013 to 2016, the Krasnodar region recorded a positive increase (0.3-0.6 people). In 2019, a natural population decline was recorded in the Krasnodar region -1.6 people per 1000 population, in Adygea - -3.1 people per 1000 population. In the Stavropol region from 2012 to 2017, there was a positive natural growth. In 2019 the population decline is recorded at the level of 1.3 people per 1000 population.

From the presented graph (fig. 1), it follows that in recent years there has been a gradual decline in the birth rate and natural growth (Gimbatov, 2013). The demographic boom that has been characteristic of the entire North Caucasus region for many years is 
Tab. 2. Indicators of the total birth rate in the subjects the North Caucasus 2010-2019

\begin{tabular}{|l|r|r|r|r|r|r|r|r|r|c|}
\hline \multicolumn{1}{|c|}{ Subject } & 2010 & 2011 & 2012 & 2013 & 2014 & 2015 & 2016 & 2017 & 2018 & 2019 \\
\hline Republic of Adygea & 1.70 & 1.66 & 1.71 & 1.68 & 1.73 & 1.72 & 1.68 & 1.52 & 1.47 & 1.38 \\
\hline Krasnodar region & 1.57 & 1.58 & 1.70 & 1.72 & 1.81 & 1.84 & 1.83 & 1.72 & 1.67 & 1.62 \\
\hline Republic of Dagestan & 1.92 & 1.98 & 2.03 & 2.02 & 2.08 & 2.02 & 1.98 & 1.91 & 1.86 & 1.80 \\
\hline Republic of Ingushetia & 2.99 & 2.94 & 2.27 & 2.23 & 2.28 & 1.97 & 1.75 & 1.77 & 1.79 & 1.83 \\
\hline Kabardino-Balkar Republic & 1.66 & 1.70 & 1.83 & 1.80 & 1.83 & 1.75 & 1.72 & 1.61 & 1.61 & 1.51 \\
\hline Karachay-Cherkess Republic & 1.51 & 1.54 & 1.63 & 1.67 & 1.65 & 1.54 & 1.52 & 1.43 & 1.43 & 1.48 \\
\hline Republic of North Ossetia-Alania & 1.84 & 1.86 & 1.96 & 1.98 & 2.01 & 1.93 & 1.89 & 1.75 & 1.83 & 1.75 \\
\hline Chechnya Republic & 3.45 & 3.36 & 3.08 & 2.92 & 2.91 & 2.80 & 2.62 & 2.73 & 2.60 & 2.58 \\
\hline Stavropol Region & 1.44 & 1.43 & 1.52 & 1.55 & 1.62 & 1.64 & 1.68 & 1.54 & 1.51 & 1.42 \\
\hline
\end{tabular}

Source: own work based on: Summarnyj...

gradually coming to an end (Dovletmurzaeva et al., 2016).

For simple replacement of generations, the total birth rate must be at least 2.14 people. According to this indicator, simple replacement of generations occurs only in the Chechen Republic (for 2019, this coefficient was 2.6). Indicators of other subjects lag far behind (table 2). Analyzing this indicator as a whole for the entire study period from 2010 to 2019, the dynamics in a number of subjects is disappointing.

Thus, despite the fact that the Chechen Republic currently occupies a leading position in terms of the total birth rate, this indicator has decreased by $25 \%$ compared to 2010 . The same dynamics is typical of the Republic of Ingushetia, where the birth rate has significantly decreased compared to 2010 - by $39 \%$. In the Republic of Dagestan at the beginning and end of the studied period, the indicators did not change much, but the peak of the indicator was in 2014 with 2.08 births. In the Republic of Adygea, the indicator also continues to decline. To date, the lowest total birth rate in the North Caucasus is observed in Adygea (1.38\%).

The table shows that the total birth rate, according to data for 2019, is quite high only in the Chechen Republic - there are 2.58 children per woman, which provides a natural increase in the population of this republic. In all other regions, this indicator is extremely low and cannot provide natural growth. It should be noted that until 2016, the birth rate had a constant increase in all regions of the North Caucasus. Since 2017, almost everywhere the total birth rate has shown a downward trend (Sigareva, 2019). This situation may indicate an impending wave of a demographic crisis associated with the economic crisis in the country.

The level of reproduction among representatives of the Caucasian peoples is much higher than that of the Russians. This is due to the deep roots of the traditional culture of the Caucasian peoples, who have preserved to this day such values as family and children. The ongoing changes in the socio-economic and political spheres of the country have little impact on the traditional culture of the peoples of the North Caucasus.

Marriage, divorce, and birth rates are closely related. Today, these processes are characterized by negative dynamics in our country. The demographic policy pursued in Russia does not have a positive effect. In general, there is a trend towards later marriage. The average age of women who married in 2018 was in the range of 18-24 years. At the same time, the peoples of the North Caucasus traditionally have the highest proportion of married women under the age of 18 in the region. According to official data, there were a record number of marriages in 2010. The maximum number of marriages in which the bride's age was under 18 was registered in the Chechen Republic in 2010 (5.8\%), followed by the Republic of Kabardino-Balkaria with a share of $4.1 \%$. By 2015 , the percentage of women who married before the age of 18 had fallen to $0.5 \%$ in the Chechen Republic and 2.4\% in Kabardino-Balkaria.

The huge difference in the proportion of men and women getting married under the age of 25 is especially noticeable. This indicates that women marry at younger ages much more often than men do. This difference is most clearly visible in the Republic of Dagestan - for 181 women married in 2018 under the age of 18 , there is only 1 man. In other regions, the difference is not so obvious, mainly due to the low number of women who marry before the age of 18.

There is a small number of women who are officially married under the age of 18 in the Chechen Republic and Ingushetia. For example, in the Chechen Republic, only 5 women and 1 man under the age of 18 were registered for 5,101 registered marriages. The situation is similar in the Republic of Ingushetia. According to the statistics below, in these republics, 
official marriage is often replaced by religious rites. As a result, according to official statistics, there is not a significant number of women who have married before the age of 18 . The same thing happens in the 18-24 age group. Most women choose to marry at these ages, while more men marry between the ages of 25 and 34 .

A surge in the number of marriages entered into occurred in 2010 in almost all regions, but in the following years there has been a steady decline in the number of marriages registered annually. In 2018, the lowest number of marriages in the last 30 years was recorded.

The number of marriages among young people under the age of 18 and women between the ages of 18 and 24 has fallen especially sharply. In the age groups from 25 to 34 and over 35, the negative trend is not so noticeable. The main reason is the gradual increase in the age of marriage and the increase in the number of people who are students and postpone marriage until graduation. The probability of remarriage also ensures that the marriage rate is maintained at older ages. In general, following the whole of Russia, the North Caucasus is gradually transitioning to the so-called European type of marriage, which is characterized by an older age of entering into marriage.

According to official data, the main number of marriages is in the age group from 18 to 24 years in most regions of the North Caucasus. The exception is the Republic of North Ossetia-Alania and the Krasnodar region, where since 2015 the largest number of marriages is performed annually at the age of 25 to 34 years. Since 2017, the same situation has been developing in the Republic of Karachay-Cherkessia. In the Stavropol region and the Republic of Adygea, there is also a gradual increase in the age of marriage. The most obvious indicator that characterizes the state of the population in marriage is the socalled marriage rate (table 3 ).

The highest marriage rate is in the Krasnodar region; the lowest one is in the Republic of Ingushetia. In comparison with 2010, in 2018, the marriage rate significantly decreased in all regions of the North Caucasus, especially in Dagestan, Ingushetia and Chechnya. It should be noted that in 2018 , the

Tab. 3. General marriage and divorce rates in the subjects of the North Caucasus (2010-2018), \%o

\begin{tabular}{|l|c|c|c|c|}
\hline \multirow{2}{*}{\multicolumn{1}{c|}{ Subject }} & \multicolumn{2}{c|}{2010} & \multicolumn{2}{c|}{2018} \\
\cline { 2 - 5 } & marriages & divorces & marriages & divorces \\
\hline Republic of Adygea & 7.9 & 3.9 & 4.5 & 3.6 \\
\hline Krasnodar Region & 8.6 & 4.5 & 6.9 & 3.8 \\
\hline Republic of Dagestan & 8.1 & 1.5 & 4.8 & 1.4 \\
\hline Republic of Ingushetia & 0.8 & 0.9 & 3.8 & 0.8 \\
\hline Kabardino-Balkar Republic & 8.2 & 2.7 & 4.5 & 2.4 \\
\hline Karachay-Cherkess Republic & 7.5 & 3.1 & 4.6 & 3.2 \\
\hline Republic Of North Ossetia-Alania & 7.1 & 2.6 & 4.7 & 2.5 \\
\hline Republic of Chechnya & 10.3 & 1.0 & 4.7 & 0.5 \\
\hline Stavropol Region & 7.5 & 4.4 & 5.0 & 3.5 \\
\hline
\end{tabular}

Source: own work based on: Čislo brakov... \& Čislo razvodov... .

Tab. 4. Number of births out of wedlock in the subjects of the North Caucasus $(2010,2015,2018)$

\begin{tabular}{|c|c|c|c|c|c|c|}
\hline \multirow{2}{*}{ Subject } & \multicolumn{2}{|c|}{2010} & \multicolumn{2}{|c|}{2015} & \multicolumn{2}{|c|}{2018} \\
\hline & Total & $\%$ & Total & $\%$ & Total & $\%$ \\
\hline Republic of Adygea & 1146 & 20.1 & 1018 & 18.1 & 790 & 17.5 \\
\hline Krasnodar Region & 14114 & 22.2 & 13993 & 18.9 & 11639 & 18.0 \\
\hline Republic of Dagestan & 9287 & 17.8 & 10680 & 19.5 & 10046 & 20.9 \\
\hline Republic of Ingushetia & 1711 & 15.3 & 1284 & 14.8 & 1038 & 12.0 \\
\hline Kabardino-Balkar Republic & 1501 & 11.9 & 1358 & 10.8 & 1105 & 10.2 \\
\hline Karachay-Cherkess Republic & 1102 & 18.0 & 976 & 16.9 & 804 & 16.1 \\
\hline Republic of North Ossetia-Alania & 2887 & 28.0 & 2317 & 22.6 & 2245 & 24.5 \\
\hline Republic of Chechnya & 1925 & 5.1 & 5957 & 18.7 & 12520 & 41.8 \\
\hline Stavropol Region & 8057 & 24.4 & 7909 & 21.7 & 6698 & 21.8 \\
\hline
\end{tabular}

Source: Demograficheskij... 
marriage and divorce rates were the lowest in the last 20 years.

The spread of unregistered marriages also plays a negative role in the dynamics of marriage, which can be indirectly evidenced by the presence of illegitimate births. From the data shown in table 4, it follows that in Russia as a whole and in the North Caucasus in particular, there has been a noticeable decrease in the number of births outside of marriage between 2010 and 2018. So, if at the turn of the century in the country almost a third of all births were outside of registered marriage, today the share of such births has fallen to $21.2 \%$, i.e. every fifth child.

This situation is observed in all regions of the North Caucasus, including Russian-speaking regions, which indicates a positive trend. Of particular note is the Republic of Kabardino-Balkaria. In 2018, it recorded the lowest number of children born out of wedlock in the country.

However, in 2018 in the Chechen Republic, slightly less than half of births occurred outside of marriage. At the same time, the number of such births in rural areas is significantly higher than in cities. This high number of children born to informally registered parents can be explained by the fact that in this republic religious rites replace the official registration of marriages.

The divorce rate has a special influence on the process of population reproduction and the formation of the marriage and family structure of society (table 3). As can be seen from table 3, the subjects of the North Caucasus are divided into two types: some are characterized by an increase in the absolute number of divorces, while others are characterized by a decrease. The first group includes Dagestan, Ingushetia, North Ossetia-Alania, Karachay-Cherkessia. The second group includes Kabardino-Balkaria, Chechnya, Adygea, Krasnodar and Stavropol regions.

According to the data shown in table 3, the highest divorce rate is observed in the Krasnodar region, followed by the Republic of Adygea and Stavropol region. The minimum percentage of divorces is in the Chechen Republic and Ingushetia, where the lowest marriage rate was recorded in 2018. In comparison with 2010, the number of divorces in 2018 in all regions of the North Caucasus slightly decreased.

Indicators of natural population growth have negative dynamics, from which it can be concluded that population growth should be sought in increasing life expectancy and migration.

To analyze the dynamics of changes in life expectancy in the subjects of the North Caucasus, refer to table 5. The table shows the average life expectancy of both sexes. For clarity, the data are for the beginning and end of the period under review -2010 and 2018. Data presented in table 5 show that life expectancy increased markedly between 2010 and 2018.

Although overall life expectancy in the North Caucasus is significantly higher than the national average, there are significant regional differences (from 73.56 in Adygea to 82.4 in Ingushetia). At the same time, from 2010 to 2018 , there was a noticeable increase in this indicator (3.0-7.7 years, depending on the region) (Kazalieva, 2019).

The difference between the life expectancy of men and women continues to decrease: in Adygea from 11.4 years in 2010 to 9.1 years in 2018, in the Krasnodar region from 10.7 to 9, in Dagestan from 7.7 to 5.6, in Ingushetia from 7.1 to 6.2, in KabardinoBalkaria from 9.7 to 8.3, Karachay-Cherkessia from 10.0 to 8.9, in North Ossetia from 11.3 to 10.2, the Chechen Republic from 6.4 to 4.7, and the Stavropol region from 10.7 to 9.2 years, respectively. The presented data show that an increase in life expectancy in many regions leads to a slight increase in the population, in particular, in the Krasnodar and Stavropol regions.

Migration is of great importance in the formation of the territorial organization of the population. Migration is the main reason for the overall population

Tab. 5. Dynamics of changes in life expectancy in the subjects of the North Caucasus in 2010 and 2018

\begin{tabular}{|l|l|l|c|}
\hline Subject & 2010 & 2018 & + /- \\
\hline Republic of Adygea & 70.0 & 73.6 & +3.6 \\
\hline Krasnodar Region & 71.0 & 74.3 & +3.3 \\
\hline Republic of Dagestan & 73.9 & 78.7 & +4.8 \\
\hline Republic of Ingushetia & 74.7 & 82.4 & +7.7 \\
\hline Kabardino-Balkar Republic & 72.1 & 76.3 & +4.2 \\
\hline Karachay-Cherkess Republic & 72.4 & 76.1 & +3.7 \\
\hline Republic Of North Ossetia-Alania & 72.7 & 75.7 & +3.0 \\
\hline Republic of Chechnya & 71.6 & 75.4 & +3.8 \\
\hline Stavropol Region & 71.0 & 74.2 & +3.2 \\
\hline
\end{tabular}

Source: Ožidaemaâ... 


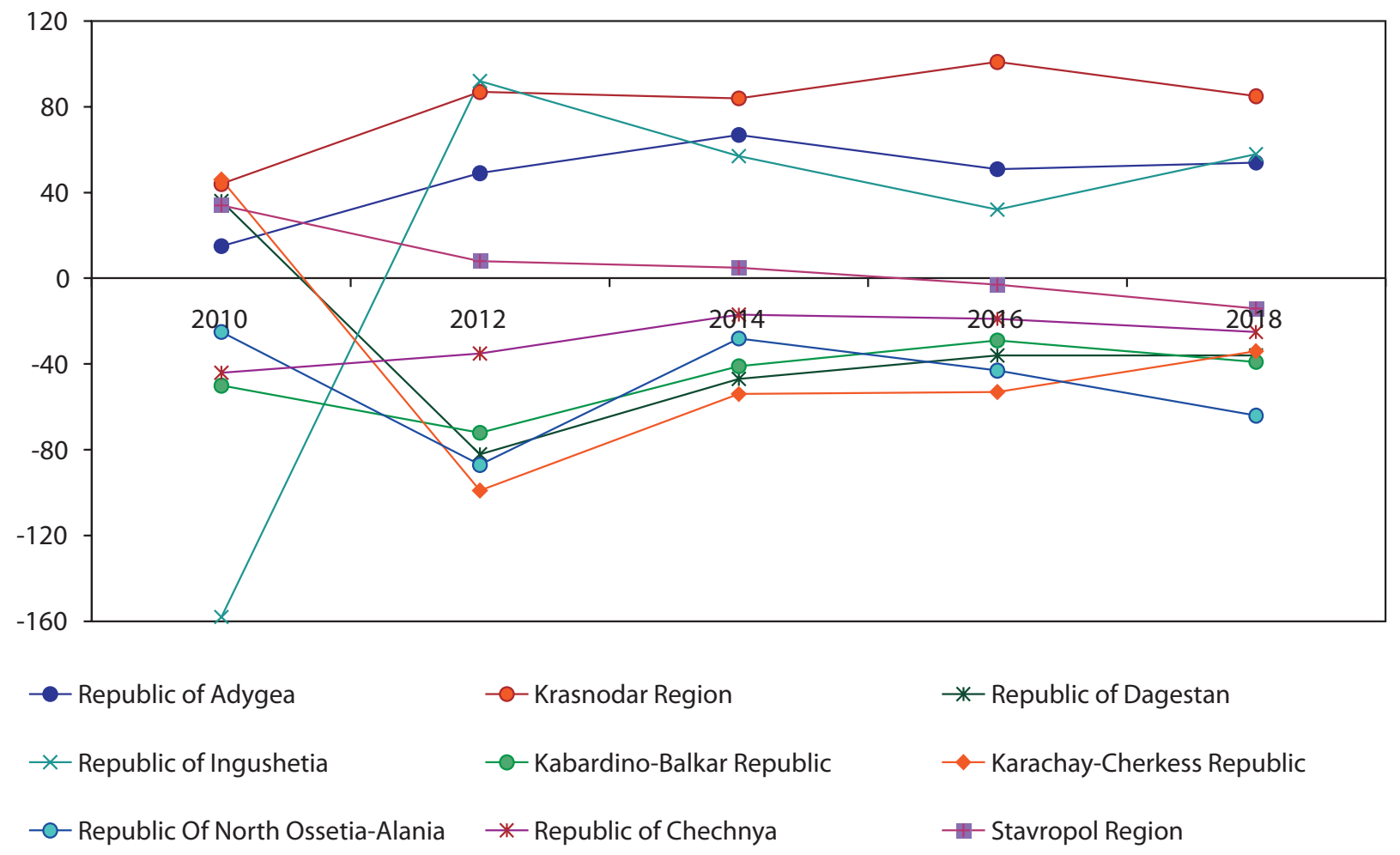

Fig. 2. Chart of changes in the migration growth of the population in the subjects of the North Caucasus for the period from 2010 to 2018 (per 10 thousand population)

Source: Koefficent...

growth in many regions of the North Caucasus, especially in the plains. Let us consider the migration growth rates in the North Caucasus regions in the period from 2010 to 2018 (fig. 2). According to fig. 2 , the largest migration growth is observed in the Krasnodar region (on average 88 people per 10 thousand population), the Republic of Adygea (on average 52 people per 10 thousand population) and Ingushetia (on average 63 people per 10 thousand population). In the Krasnodar region, the peak of migration growth occurred in 2013. The following years showed a slight decrease in the migration rate, but the migration growth remains quite high in comparison with other areas of the region.

In the period from 2010 to 2014, the Stavropol region had a low positive migration balance; since 2015 there has been a gradually increasing negative migration growth of the population. KarachayCherkessia, Kabardino-Balkaria, Dagestan, and North Ossetia-Alania consistently have high rates of migration outflow (Abdulmanapov, 2016).

In the subjects of the North Caucasus with a young age structure of the population - the republics of Chechnya and Dagestan - the population is growing due to a high birth rate, low mortality rate and high life expectancy, which covers the negative balance of migration.

It can be seen from fig. 2 that the North Caucasus demonstrates high indicators of migration dynamics.
Since most of the subjects of the North Caucasus are agricultural, the crisis in the agro-industrial complex of the country hit them the most strongly. This led to a general decline in the level of income and the quality of life of the population, which is especially pronounced in the national republics of the region (Minenkova et al., 2016). It encourages the excess part of the working-age population, especially young people, to look for a place to apply their forces outside their republics. For example, the main migration flows of North Ossetia-Alania are directed to the Rostov region, Krasnodar and Stavropol regions, as well as the Central Federal district. There are less significant migration links with other regions. From the Republic of Dagestan, the main flow of population is also directed to the Krasnodar and Stavropol regions, the Central and Ural Federal districts. It is obvious that the main part of migration flows occurs within the North Caucasus economic region. A significant number of migrants from the national republics settle in the more attractive socio-economic Krasnodar and Stavropol regions.

It should be noted that a significant increase in the population in recent years, for example, in the Krasnodar region is not associated with a high natural growth. The growth of the population of this region is directly related to high migration inflows, both from the Northern regions of the Russian Federation and from nearby subjects of the North 


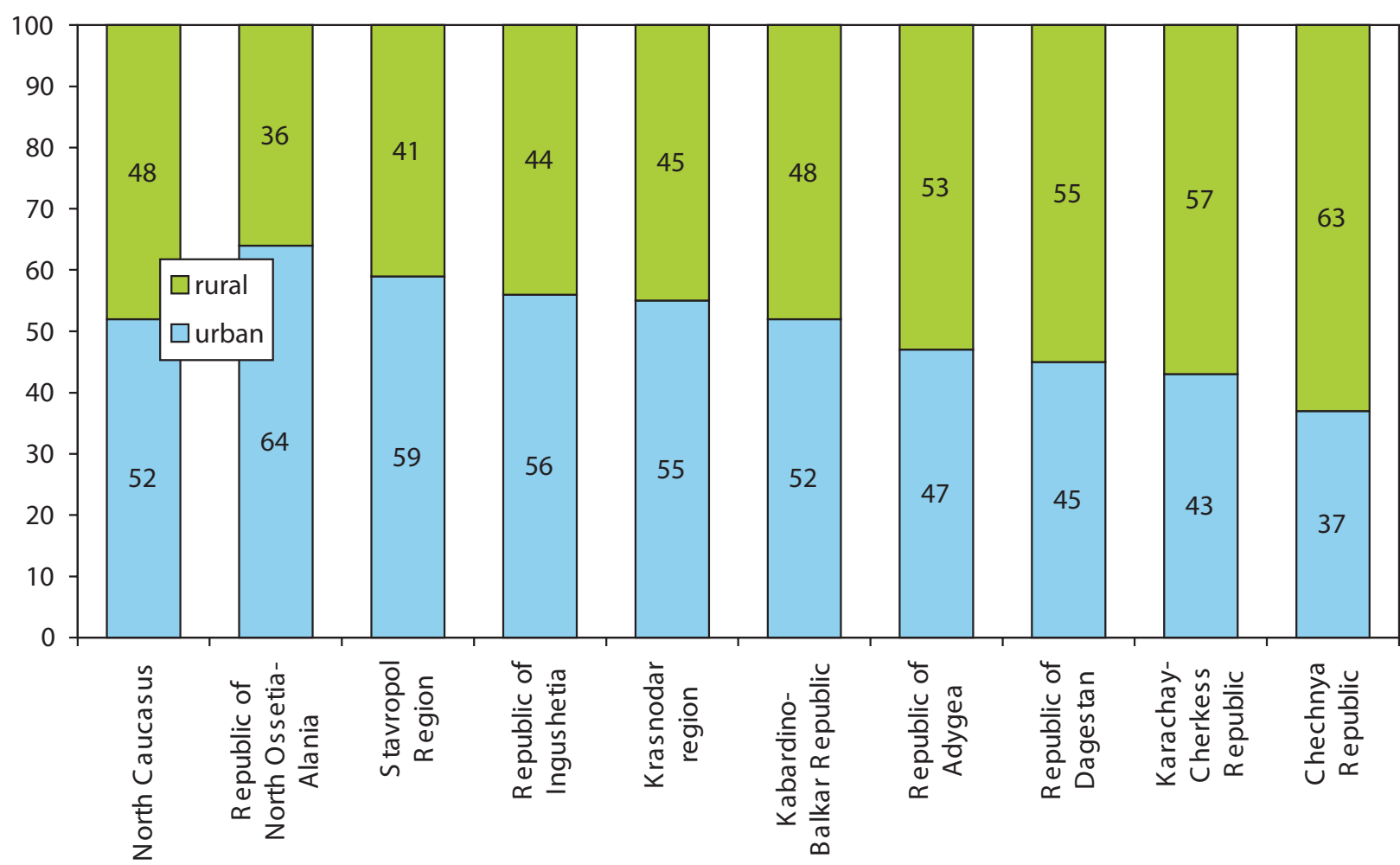

Fig. 3. The ratio of urban and rural population in the subjects of the North Caucasus (in \%, as of 01.01.2019) Source: Čislennost'...

Caucasus, since the excess of the young workingage population, as noted above, is concentrated in the republics of the North Caucasus. The analysis of the age structure of migrants allows us to conclude that more than half of those who arrived in the Krasnodar region are people of working age (from 15 to 40 years). Based on these data, we can conclude that through an increase in the share of the working-age population, for example, in the Krasnodar region, the average age of the population decreases, due to which the mortality rates in the subject fall.

The North Caucasus continues to be the least urbanized territory of the Russian Federation (Zhornickaya, 2016). On average, the share of the urban population remains at 52\% (fig. 3). In Dagestan, Adygea, Karachay-Cherkessia and Chechnya, most of the population lives in rural areas. In all other regions of the North Caucasus, the level of urbanization is lower than the national average (Anohin et al., 2014). The most urbanized region is the Republic of North Ossetia-Alania with an indicator of $64 \%$. A characteristic feature of the North Caucasus region is the growth of the urban population with an even greater increase in the rural population, which leads to a reduction in the share of the urban population (Tavasiev, Okazova, 2014).

Uneven growth rates of urban and rural populations predetermined the formation of different types of dynamics (table 6).
In the territory of five regions, including «rural» Dagestan and Ingushetia, the share of the urban population is steadily increasing. Within Ingushetia, the level of urbanization exceeded the 50 percent mark in 2018, while in 2017 the share of the urban population was $41.8 \%$. The share of the urban population of Dagestan is increasing at a slow pace and has not reached the 50 percent level yet.

In four republics, there is an increase in the rural population. The share of the rural population is increasing most rapidly in Adygea. Over 9 years, the share of the urban population here has decreased by $3.9 \%$.

Differences in the growth rates of urban and rural populations affect changes in their location. The difference in reproduction processes, which are most clearly manifested as a result of increasing differentiation between natural growth levels, as well as intensive migration processes is an important factor affecting population redistribution.

\section{Conclusion}

In general, the demographic situation in the North Caucasus has positive dynamics - the birth rate is growing, the death rate is decreasing, and the average life expectancy is increasing. However, it should be borne in mind that population reproduction is 
Tab. 6. Grouping of North Caucasus regions by types of population dynamics and structure in 2010 and 2019

\begin{tabular}{|l|c|c|}
\hline \multirow{2}{*}{\multicolumn{2}{|c|}{}} & \multicolumn{2}{|c|}{ Percentage of urban population, \% } \\
\cline { 2 - 3 } & \multicolumn{2}{|c|}{2019} \\
\hline Subjects with the growth of the urban population & 52.8 & 55.2 \\
\hline Krasnodar region & 44.8 & 45.3 \\
\hline Republic of Dagestan & 42.7 & 55.5 \\
\hline Republic of Ingushetia & 63.7 & 64.3 \\
\hline Republic Of North Ossetia-Alania & 57.0 & 58.6 \\
\hline Stavropol region & & \\
\hline Subjects with a growing rural population & 51.0 & 47.1 \\
\hline Republic of Adygea & 54.7 & 52.1 \\
\hline Kabardino-Balkar Republic & 43.7 & 42.8 \\
\hline Karachay-Cherkess Republic & 36.8 & 36.7 \\
\hline Republic of Chechnya & & \\
\hline
\end{tabular}

Source: Čislennost'...

mainly due to an increase in life expectancy and migration. The total fertility rate is too low to ensure simple reproduction, and the forecasts do not foresee its growth. Despite the general decline in population growth rates, growth will continue in the coming years, but there is an urgent need for a competent socio-demographic policy, and the need to reduce migration outflow, especially from national republics. To do this, it is necessary to create new jobs, develop social, transport and recreational infrastructure.

On the other hand, the state should create conditions for the successful integration of migrants in regions of the country with negative natural population growth, and develop mechanisms for managing the settlement of migrants on the territory of the Russian Federation.

The current socio-economic situation in the North Caucasus and in Russia as a whole requires a change in attitude to the state's migration policy. A competent migration policy should be one of the government's priorities.

\section{References}

Abdulmanapov P.G., 2016, Sovremennaâ demografičeskaâ situaciâ v Severo-Kavkazskom Federal'nom okruge (Eng. Current demographic situation in the North Caucasus Federal district), [in:] Aktual'nye problemy social'notrudovyh otnošenij: materialy VI Vserossijskoj naučnopraktičeskoj konferencii s meždunarodnym učastiem, posvâŝennoj 85-letiû obrazovaniâ Dagestanskogo gosudarstvennogo universiteta (Eng. Actual problems of social and labor relations. Materials of the VI All-Russian scientific and practical conference with international participa- tion dedicated to the 85th anniversary of Dagestan state University), Approbation, Makhachkala, 39-41.

Anohin A.A., Zhitin D.V., Krasnov A.I., Lachininskij S.S., 2014, Sovremennye tendencii dinamiki čislennosti naseleniâ gorodov Rossii (Eng. Current trends in population dynamics in Russian cities), Vestnik Sankt-Peterburgskogo universiteta. Seriâ 7. Geologiâ. Geografiâ, 4, 167-179.

Čislennost' nostoânnogo naseleniâ na 1 ânvapâ (Eng. Permanent population as of January 1), EMISS gosudarstviennaâ statistika, https://showdata.gks.ru/report/278928 (accessed 27 June 2020).

Čislo brakov v pasčete na 1000 naseleniâ za god (Eng. Number of marriages per 1000 population per year), EMISS gosudarstviennaâ statistika, https://showdata.gks.ru/report/297890 (accessed 27 June 2020).

Čislo razvodov $v$ pasčete na 1000 naseleniâ za god (Eng. Number of divorces per 1000 population per year), EMISS gosudarstviennaâ statistika, https://showdata.gks.ru/report/297892 (accessed 27 June 2020).

Demograficheskij ezhegodnik Rossii, 2012, https://rosstat.gov. ru/bgd/regl/B12_16/Main.htm (accessed 06 November 2020).

Demograficheskij ezhegodnik Rossii, 2017, https://rosstat.gov. ru/bgd/regl/B17_16/Main.htm (accessed 06 November 2020).

Demograficheskij ezhegodnik Rossii, 2019, https://rosstat.gov. ru/bgd/regl/B19_16/Main.htm (accessed 06 November 2020).

Dinaev A.M., 2016, AnalizdemografičeskoysituaciivČečensko yrespublikena 1 iûlâ 2016 goda (Eng. Analysis of the demographic situation in the Chechen Republic as of July 1, 2016), Psihologia, sociologia i pedagogika, 8(59), 54-56.

Dovletmurzaeva M.A, Nazirov D.T., Mehtiev Sh.R., 2016, Tendenciâ demografičeskoy situacii v Čečenskoy Respublike (Eng. Trend of the demographic situation in the Chechen Republic), European Research, 12(23), 50-51.

Estestvennyj prirost $v$ pasčete na 1000 naseleniâ (Eng. Natural growth per 1000 population), EMISS gosudarstviennaâ statistika, https://showdata.gks.ru/report/297732 (accessed 27 June 2020). 
GimbatovSh.M.,2013Osobennosti social'no-demografičeskoj situacii na Severnom Kavkaze (Eng. Features of the sociodemographic situation in the North Caucasus), Biznes. Obrazovanie. Pravo, 4(25), 224-227.

Kazalieva A.V., 2019, Analiz pokazatelej demografičeskogo stareniâ naseleniâ Severnogo Kavkaza (Eng. Analysis of indicators of demographic aging of the population of the North Caucasus), [in:] Teoretičeskie i prikladnye problemy geografičeskoj nauki: demografičeskij, social'nyj, pravovoj, ekonomičeskij i ekologičeskij aspekty: materialy meždunarodnoj naučno-praktičeskoj konferencii: v 2. T.1. (Eng. Theoretical and applied problems of geographical science: demographic, social, legal, economic and environmental aspects. Materials of the international scientific and practical conference), VGPU, Voronezh, 615-620.

Kazalieva A.V., Minenkova V.V., 2019, Naselenie Severnogo Kavkaza na sovremennom ètape: dinamika i faktory regional'noj differenciacii (Eng. Population of the North Caucasus at the present stage: dynamics and factors of regional differentiation), [in:] Ustojčivoe razvitie gornyh territorij Kavkaza. Kollektivnaâmonografiâ, Tom II (Eng. Sustainable development of the mountain territories of the North Caucasus. Collective monograph), SKGMI, Vladikavkaz, 520-526.

Kazalieva A.V., Minenkova V.V., Mamonova A.V., 2018, Retrospektivniy analiz dinamiki izmeneniâčislennosti naselenâ Severnogo Kavkaza (Eng. Retrospective analysis of population dynamics in the North Caucasus), Izvestâ Dagestanskogo gosudarstvennogo pedagogičeskogo univesiteta. Estestvennye I tochnye nauki, 12(2), 89-94.

Koefficient migracionnogo prirosta na 10000 čelovek naseleniâ (Eng. Migration growth rate per 10,000 population), EMISS gosudarstviennaâ statistika, https://showdata.gks. ru/report/279008 (accessed 27 June 2020).

Minenkova V.V., Kazalieva A.V., 2020, Osnovnye tendencii smertnosti naseleniâ Severnogo Kavkaza v postsovetskij period (Eng. Main trends in mortality in the North Caucasus in the post-Soviet period), Učenye zapiski Krymskogo federal'nogo universiteta imeni V.I. Vernadskogo. Geografiâ. Geologiâ, 6(1), 43-55.

Minenkova V.V., Kuziakina M.V., Mamonova A.V., 2016, Demografičeskaâ situaciâ na Kavkaze (Eng. Demographic situation in the Caucasus), [in:] Geoinformacionnoe kartografirovanie v regionah Rossii: materiali VII Vserossiiskoy naučno-practičeskoy konferencii (Eng. GIS mapping in the regions of Russia: materials of the VII all-Russian scientific and practical conference), Scientific book, Voronezh, 68-72.

Ožidaemaâ prodolžitel'nost' žizni pri roždenii (Eng. Life expectancy at birth), EMISS gosudarstviennaâ statistika, https:// www.fedstat.ru/indicator/31293 (accessed 27 June 2020).

Regiony Rossii. Social'no-ekonomičeskie pokazateli. (Eng. Regions of Russia. Socio-economic indicators), 2019, Rosstat, Moskva, 43-46.

Sigareva E.P., 2019, Novoe v semejnyh otnošeniâh: vzglâd molodeži Severnogo Kavkaza (Eng. New in family relations: the view of the youth of the North Caucasus), [in:] Demografičeskij imigracionnyj portret Kavkaza (Eng. De- mographic and migration portrait of the Caucasus), EkonInform, Moscow, 46-57.

Summarnyj koèfficient roždaemosti (Eng. Total fertility rate), EMISS gosudarstviennaâ statistika, https://www.fedstat. ru/indicator/31517 (accessed 27 June 2020).

Tavasiev V.H., Okazova Z.P., 2014, Dinamika čislennosti gorodskogo i sel'skogo naseleniâ Severnogo Kavkaza (Eng. Dynamics of the urban and rural population of the North Caucasus), Sovremennye problemy nauki i obrazovaniâ, 6 , 1596.

Zhornickaya O.B., 2016, Urbanizaciâ kak faktor uspešnogo ekonomičeskogo razvitiâ gorodov Kavkaza (Eng. Urbanization as a factor of successful economic development of cities in the Caucasus), [in:] Razvitie territorial'nyh social'noekonomičeskih sistem: voprosy teorii i praktiki: sbornik naučnyh statej XIV Meždunarodnoj naučno-praktičeskoj konferencii molodyh učonyh (Eng. Development of territorial socio-economic systems: questions of theory and practice: collection of scientific articles of the XIV International scientific and practical conference of young scientists), Institute of Economics of the Ural branch of the Russian Academy of Sciences, Yekaterinburg, 295-297. 